\title{
Cigarette Smoke Inhalation Influences Bone Healing of Post-Extraction Tooth Socket: A Histometric Study in Rats
}

\author{
Ana Paula Oliveira GIORGETTI ${ }^{1}$ \\ João Batista CÉSAR NETO² \\ Márcio Zaffalon CASATI ${ }^{1}$ \\ Enílson Antonio SALLUM ${ }^{1}$ \\ Francisco Humberto NOCITI JÚNIOR ${ }^{1}$ \\ ${ }^{1}$ Department of Prosthodontics and Periodontics, Periodontics Division, Piracicaba Dental School, \\ UNICAMP - University of Campinas, Piracicaba, SP, Brazil \\ ${ }^{2}$ Department of Stomatology, Periodontics Division, Dental School, USP - University of São Paulo, São Paulo, SP, Brazil
}

\begin{abstract}
The aim of this study was to evaluate, histometrically, the bone healing of the molar extraction socket just after cigarette smoke inhalation (CSI). Forty male Wistar rats were randomly assigned to a test group (animals exposed to CSI, starting 3 days before teeth extraction and maintained until sacrifice; $\mathrm{n}=20$ ) and a control group (animals never exposed to CSI; $\mathrm{n}=20$ ). Second mandibular molars were bilaterally extracted and the animals ( $\mathrm{n}=5 /$ group/period) were sacrificed at 3, 7, 10 and 14 days after surgery. Digital images were analyzed according to the following histometric parameters: osteoid tissue (OT), remaining area (RA), mineralized tissue (MT) and non-mineralized tissue (NMT) in the molar socket. Intergroup analysis showed no significant differences at day 3 ( $p>0.05$ ) for all parameters. On the $7^{\text {th }}$ day, CSI affected negatively $(\mathrm{p}<0.05)$ bone formation with respect to NMT and RA (MT: $36 \%$, NMT: $53 \%$, RA: $12 \%$; and MT: 39\%, NMT: 29\%, RA: 32\%, for the control and test groups, respectively). In contrast, no statistically significant differences $(p>0.05)$ were found at days 10 and 14 . It may be concluded that CSI may affect socket healing from the early events involved in the healing process, which may be critical for the amount and quality of new-bone formation in smokers.
\end{abstract}

Key Words: cigarette, bone, healing, tooth socket, rat.

\section{INTRODUCTION}

A favorable architecture of the alveolar ridge with sufficient alveolar bone volume is essential to obtain a functional and esthetic prosthetic rehabilitation. Therefore, knowledge about the healing process at extraction sites is essential to avoid insufficient bone volume. The healing events in the tooth extraction socket culminate in the formation of woven bone, which ultimately remodels, resulting in the restoration of the defect (1). In general, smoking exerts an adverse effect on bone and decreases the blood filling of postextraction sockets; consequently, it has an adverse effect on healing of the extraction wound (2). A 15-patient clinical study revealed that $80 \%$ of the individuals who underwent intraoral bone grafting with simultaneous implant placement, and experienced impairment of bone healing, were smokers (3). In vitro studies have also associated cigarette compounds with negative events at the cellular level. Nicotine has been shown to have detrimental effects on periodontal cells in a variety of ways. In vitro studies have shown nicotine negatively affected osteoblasts (4), inhibited gingival fibroblast growth and production of fibronectin and collagen, while promoting collagen breakdown (5). It also affects periodontal ligament fibroblasts (6) and stimulates osteoclasts activity $(4,7)$. In addition, it has been reported that acrolein and acetaldehyde, volatile components of cigarette smoke, also have a negative effect on fibroblast cultures (8).

A meta-analysis evaluating prospective clinical studies (9) reported the magnitude of the association

Correspondence: Dra. Ana Paula Oliveira Giorgetti, Departamento de Prótese e Periodontia, UNICAMP, Avenida Limeira 901, Areião, 13414-903 Piracicaba, SP, Brasil. Tel/Fax: +55-19-2106-5301. email: anagetti@hotmail.com 
between cigarette smoking and bone mass and showed that smokers presented significantly reduced bone mass, compared with non-smokers. Saldanha et al. (10), following a 6-month prospective study, suggested that smoking may affect significantly the remodeling process after tooth extraction. In this study, a slight change in alveolar bone height (about $1 \mathrm{~mm}$ ) was observed for non-smokers while smokers lost significantly more (1.5 $\mathrm{mm})$. However, the impact of smoking on bone healing just after cigarette smoke inhalation is not known. Previous studies $(6,10,11)$ have evaluated the influence of nicotine on the bone healing of extraction sockets, but there are compounds of cigarette smoke that are as harmful as nicotine (11) and should also be evaluated.

The influence of long-term smoking in such a scenario is evident, but the bone healing of the extraction socket just after the cigarette smoke inhalation has never been investigated. Thus, the aim of this study was to evaluate, histometrically, whether cigarette smoking inhalation may affect socket healing at the early events of the bone healing process following molar tooth extraction, in rats.

\section{MATERIAL AND METHODS}

\section{Animals}

Forty male Wistar rats (300 - $400 \mathrm{~g})$ were used in the study. The animals were kept in plastic cages with access to food and water ad libitum. The protocols were approved by the University of Campinas Animal Care and Use Committee (Protocol \#\# 1572-1).

\section{Experimental Design}

The animals were randomly assigned to one of the following groups: test group: animals were intermittently housed in an exposure device for $8 \mathrm{~min}, 3$ times daily, when they were exposed to CSI $(n=20)$; control group, same as described, except that the animals were not exposed to CSI at any time during the experimental period $(n=20)$. Briefly, the device consisted of a $45 x$ $25 \times 20 \mathrm{~cm}^{3}$ clear acrylic chamber, an air pump and two inflow/outflow tubes.

Five animals were placed in the chamber at the same time and the cigarette smoke of 10 cigarettes, each containing $1.3 \mathrm{mg}$ of nicotine, $16.5 \mathrm{mg}$ of tar and 15.2 $\mathrm{mg}$ of carbon monoxide was pumped into the chamber. The serum levels of nicotine and cotinine obtained by using this model have been reported previously (12). All animals included in the study had their mandibular second molars extracted bilaterally and the exposure to the cigarette smoke started 3 days before extraction surgery for the test group. The control animals were also housed 3 days before extraction surgery, but were not exposed to the cigarette smoke (sham procedure). The animals were sacrificed at $3,7,10$ and 14 days after surgery $(\mathrm{n}=5 /$ group/period $)$.

\section{Surgical Technique}

Under general anesthesia, both mandibular right and left second molars were luxated and pulled out of the sockets. The sockets were curetted and abundantly irrigated, aiming for removal of residual fragments of hard and soft tissues that could interfere with healing. The soft tissues were then closed with 5-0 nylon (Mononylon; Ethicon, São Paulo, SP, Brazil). The animals were maintained on a soft diet for 7 days after extraction and then changed to a normal diet until euthanasia. Water was given ad libitum during the whole experimental period and sutures were removed 7 days after tooth extraction.

\section{Histometric Analysis}

After euthanasia, the hemimandibles were fixed in $4 \%$ neutral formalin for $48 \mathrm{~h}$ and subsequently decalcified in $10 \%$ EDTA, $\mathrm{pH}=7.4$ for histometric analysis. Paraffin-embedded 6 - $\mu$ m-thick serial sections were obtained in a buccolingual direction from the mesial root of the mandibular second molar and stained with hematoxylin and eosin. After identification of the first and the last section in which the socket was evident, five equally distant sections from each other were selected for histometric analysis. Using an image- analysis system (Image-Pro; Media Cybernetics, Silver Spring, MD, USA), with reticuled grid, the following parameters were histometrically evaluated in the molar socket by a blinded examiner: osteoid tissue (OT; only at day 3), remaining area (RA - part of the socket not filled with osteoid tissue or bone), mineralized tissue (MT) and non-mineralized tissue (NMT) .

\section{Statistical Analysis}

Descriptive statistics (mean, standard error) for each histometric parameter were calculated and a general average was obtained for each group. Intra- 
group analysis passed by a normality test (ShapiroWilk, $p=0.7844$ ) and then were carried out by the One-Way ANOVA parametric test $(\alpha=0.05)$. When the ANOVA test showed a significant difference, StudentNewman-Keuls pairwise multiple-comparison test was used. For the inter-group analysis, a f-test was used to verify homogeneous or heterogeneous variances and the Student's t-test $(\alpha=0.05)$ was used assuming homogeneous variances to test the hypothesis that smoking would not affect new bone formation after tooth extraction.

\section{RESULTS}

The control and the test groups showed a similar wound healing sequence over time. MT was directly proportional to the periods of euthanasia. With regard to the histometric parameters, there was a significant increase $(p \leq 0.05)$ in MT and a significant decrease $(\mathrm{p} \leq 0.05)$ in RA and NMT, over time, in the intra-group analysis for both groups. Furthermore, inter-group analysis showed that CSI (test group) decreased significantly NMT and increased significantly RA $(\mathrm{p} \leq 0.05)$, at day 7 .

No statistically significant differences $(\mathrm{p}>0.05)$ were observed at the other periods of euthanasia. The results of OT $(p=0.643)$ and $\mathrm{RA}(\mathrm{p}=0.683)$ after 3 days show that CSI did not interfere in new bone formation for any parameter. At day 7, CSI interfered in new bone formation, reducing significantly NMT $(p \leq 0.001)$ and increasing significantly RA ( $\mathrm{p} \leq 0.001)$, but it did not interfere in MT formation ( $p=0.731$ ). At day 10 , CSI did not interfere in new bone formation for $\mathrm{MT}(\mathrm{p}=0.123)$, RA ( $p=0.522)$ or NMT $(p=0.100)$. At day 14 , CSI did not interfere in new bone formation for $\mathrm{MT}(\mathrm{p}=0.920)$, RA ( $p=0.443)$ and NMT $(p=0.348)$ (Table 1$)$.

Histological sections representing the results of each group are shown in detail in Figures 1 to 4.

\section{DISCUSSION}

The present investigation demonstrated that CSI influences bone healing since the early phases of the process. Smoking promoted a significant decrease in NMT at day 7 and, consequently, an increase in RA. This finding may be of clinical significance when considering early implant placement. Recently, the early approach for implant placement has been suggested for several clinical situations. However, there is a lack of data regarding the influence of risk factors for implant placement (including smoking) on the early phases of socket healing. To the best of our knowledge, the only study (6) that evaluated histologically the impact of smoking on socket healing used subcutaneous injections of nicotine, administered (once or twice daily) for a period of 4 weeks before maxillary right incisor extraction, until euthanasia day $(3,7,15$ and 28 days after surgery). Similarly to the present results, a significant negative influence of nicotine on bone formation appeared only at day 7 , showing a partially filled socket with newly formed connective tissue and a considerable amount of remaining blood clot. Although the difference regarding the period of euthanasia limits the comparison between the studies, the present results

Table 1. Percentage (\%) and standard deviation (SD) of bone healing for control and test groups at each period of euthanasia.

\begin{tabular}{|c|c|c|c|c|c|c|c|c|}
\hline \multirow{2}{*}{ Time } & \multicolumn{4}{|c|}{ Control group } & \multicolumn{4}{|c|}{ Test group } \\
\hline & OT & MT & NMT & RA & OT & MT & NMT & RA \\
\hline 3 days & $23(0.07)^{\mathrm{A}}$ & -- & -- & $77(0.07)^{\mathrm{aA}}$ & $21(0.03)^{\mathrm{A}}$ & -- & -- & $79(0.03)^{\mathrm{cA}}$ \\
\hline 7 days & -- & $36(0.08)^{\mathrm{aA}}$ & $53(0.21)^{\mathrm{aA}}$ & $12(0.16)^{\mathrm{bA}}$ & - & $39(0.16)^{\mathrm{aA}}$ & $29(0.15)^{\mathrm{abB}}$ & $32(0.31)^{\mathrm{aB}}$ \\
\hline 10 days & -- & $49(0.02)^{\mathrm{bA}}$ & $40(0.03)^{\mathrm{bA}}$ & $11(0.02)^{\mathrm{bA}}$ & - & $54(0.04)^{\mathrm{bA}}$ & $32(0.07)^{\mathrm{bA}}$ & $14(0.08)^{\mathrm{bA}}$ \\
\hline 14 days & -- & $63(0.08)^{\mathrm{cA}}$ & $27(0.07)^{\mathrm{cA}}$ & $10(0.06)^{\mathrm{bA}}$ & - & $64(0.06)^{\mathrm{bA}}$ & $22(0.04)^{\mathrm{aA}}$ & $14(0.06)^{\mathrm{bA}}$ \\
\hline
\end{tabular}

OT: osteoid tissue; MT: mineralized tissue; NMT: non-mineralized tissue; RA: remaining area. Different lowercase letters indicate statistically significant intragroup difference (ANOVA and Student-Newman-Keuls, $\mathrm{p} \leq 0.05$ ). Different uppercase letters indicate statistically significant intergroup difference (Student's t-test, $\mathrm{p} \leq 0.05$ ). 
at day 14 and those of Pinto et al. (6) at day 15 may have some similarities despite the experimental model (CSI versus nicotine administration). The present study showed a numerical tendency for increased RA and for lower NMT formation at day 14 for the test group (CSI inhalation) and Pinto et al. (6) observed thin and isolated bone trabeculae, with discrete angiogenesis at day 15 , reinforcing the hypothesis of the early influence of smoking on bone healing.

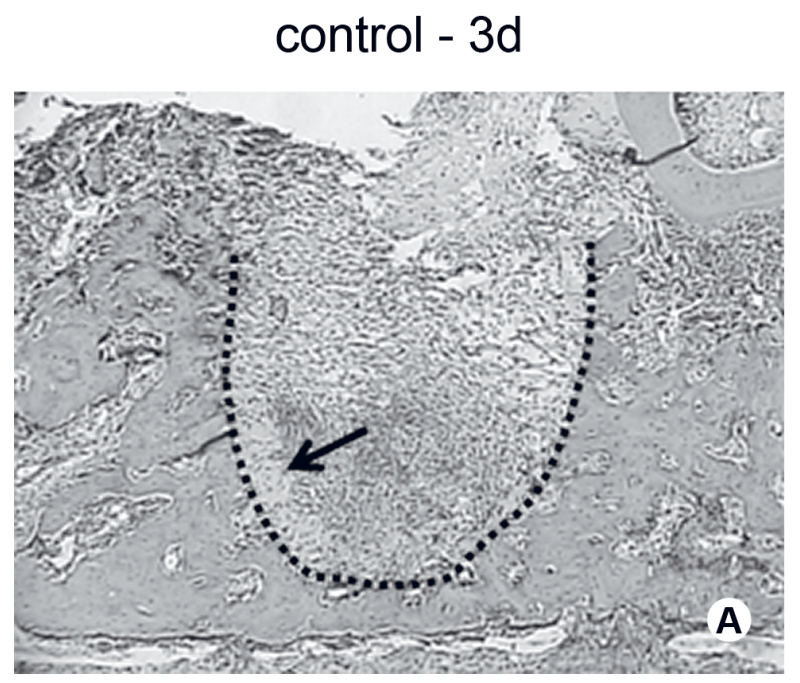

The present results are also in agreement with those of a clinical study (10), which evaluated radiographically, in humans, the bone pattern of extraction sockets of smokers and non-smokers. The authors reported that smoking enhanced bone resorption after extraction (decreasing bone height) and reduced the density of both newly formed and preexisting bone. The results of the present study are also supported by previous histological reports that showed a harmful

Figure 1. Photomicrograph illustrating new bone formation at 3 days (control and test groups). Note the presence of periodontal ligament remnants (arrows). These photomicrographs were used for the histometric counting. Dotted line delimits tooth socket and new bone formation (Hematoxylin and eosin, original magnification $\times 10$ ).
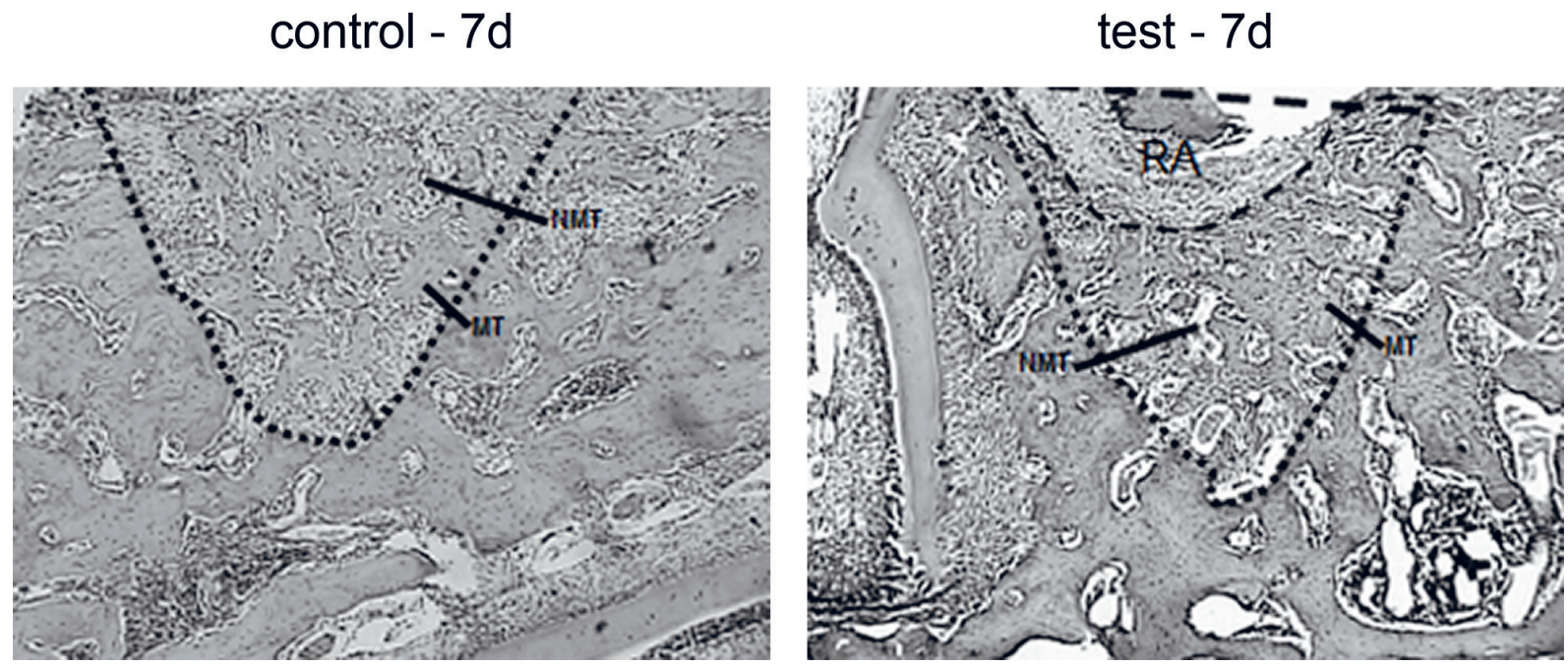

Figure 2. Photomicrograph illustrating new bone formation at 7 days (control and test groups). Small newly formed bone trabeculae, mineralized tissue (MT) and non-mineralized tissue (NMT) can be seen in the control group. The remaining area (RA) is larger in the test group than in the control group. These photomicrographs were used for the histometric counting. Dotted line delimits tooth socket and new bone formation (Hematoxylin and eosin, original magnification $\times 10$ ). 
effect of CSI on bone healing around implants (13), bone density adjacent to implants (14), self-healing capacity of periodontal defects (15) and alveolar bone density (12). Although some of these studies (12-14) show an adverse effect of CSI on bone healing for longer periods of time, the present study showed that, even for short periods of time, CSI already has harmful effects on bone healing, as demonstrated at day 7. This finding demonstrates a possible clinical implication on the quality of the residual bone ridge after tooth extraction in smokers and, consequently, on the rehabilitation by either osseointegrated implants or fixed/removable conventional prostheses during the early phases of socket healing.

Part of the negative influence of smoking on the healing process has been attributed to nicotine, which

\section{control - 10d}

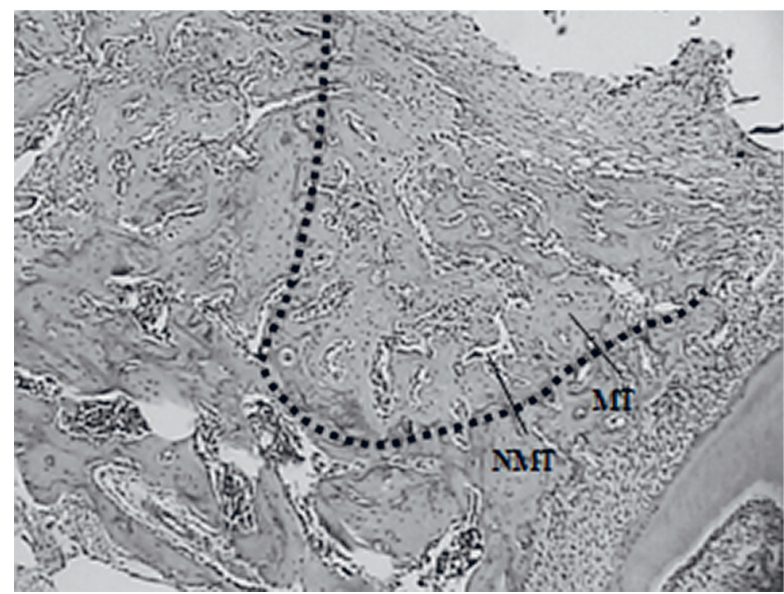

test - 10d

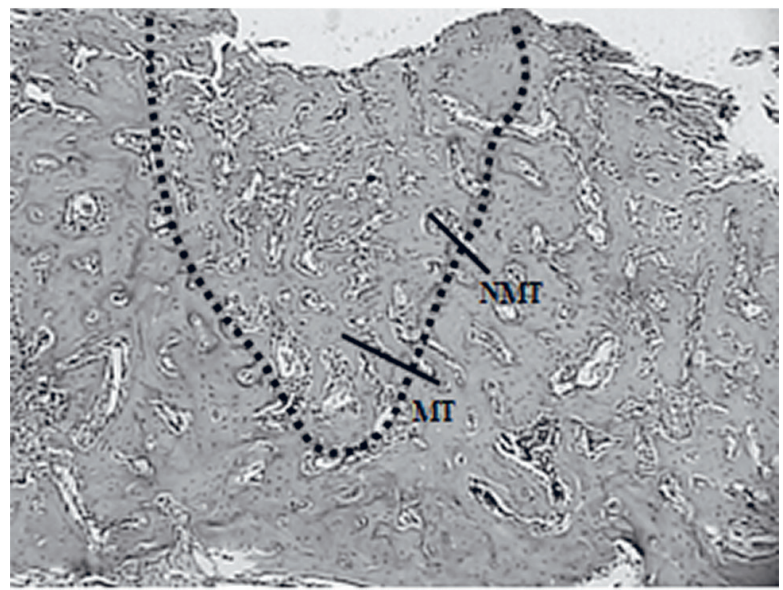

Figure 3. Photomicrograph illustrating new bone formation at 10 days (control and test groups). Regular and thin bone trabeculae can be observed in both groups. Mineralized (MT) and non-mineralized tissue (NMT) are indicated. These photomicrographs were used for the histometric counting. Dotted line delimits tooth socket and new bone formation (Hematoxylin and eosin, original magnification $\times 10$ ).

\section{control - 14d}

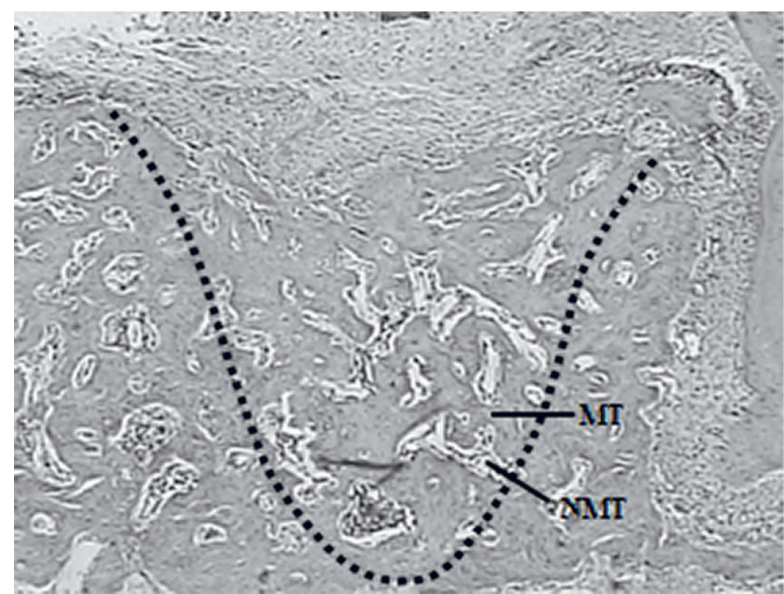

test - 14d

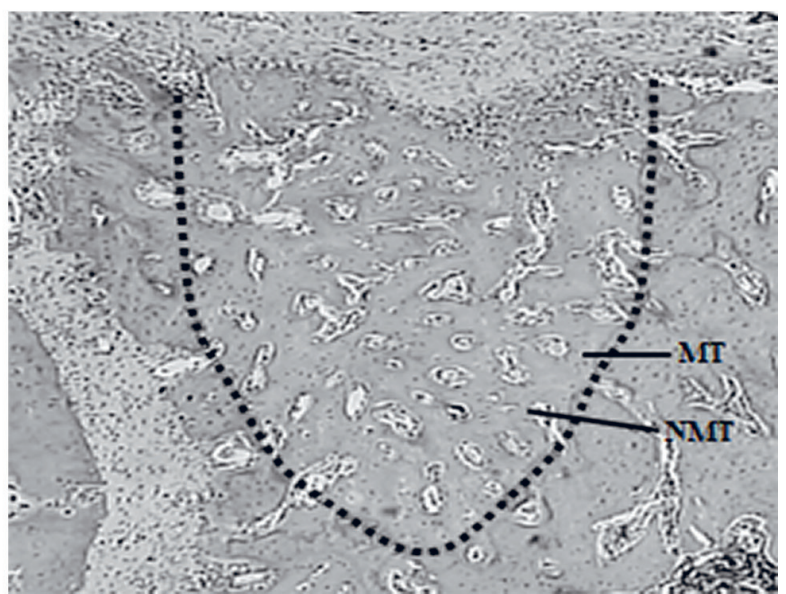

Figure 4. Photomicrograph illustrating new bone formation at 14 days (control and test groups). The socket was almost completely filled with well-defined trabecular bone in both groups. Mineralized (MT) and non-mineralized tissue (NMT) are indicated. These photomicrographs were used for the histometric counting. Dotted line delimits tooth socket and new bone formation (Hematoxylin and eosin, original magnification $\times 10$ ). 
is one of the major constituents of the particle phase of tobacco smoke and its most cytotoxic and vasoactive substance. In vivo and in vitro studies have shown that nicotine inhibits revascularization (16) and also inhibits the expression of a wide range of cytokines including those associated with new vessel formation (16) and osteoblast differentiation (6). In a study with similar methodology (17), Atp6v0d2 (an osteoclast specific marker) ${ }_{m}$ RNA levels were found to be significantly increased on day 7 for the CSI group. The RANKL/ OPG ratio was also observed. While a tendency towards a decreased RANKL/OPG ratio over time was observed for the non-exposed group, starting at day 7 , a gradual increase was found over time when the animals were exposed to CSI. Changes in RANKL/OPG ratio have been reported to affect the bone remodeling process, and an increase in this ratio may occur during the initiation of bone resorption (18). Moreover, CSI markedly affected the expression of alkaline phosphatase activity (associated with the formation of calcified tissues) (17). The animals submitted to CSI had significantly lower $\mathrm{ALP}_{\mathrm{m}}$ RNA levels than the control group at days 7 and 10. Thus, it may be speculated that CSI can cause damage to the new bone formation, starting at day 7 , increasing the expression of genes related to bone resorption and decreasing the expression of genes related to bone formation.

The present histological results illustrate part of our previous findings observed at the molecular level (17). Giorgetti et al. (17) showed that, despite the influence of CSI on genes related to bone formation and resorption, CSI was not able to avoid bone formation. The expression of bone morphogenetic proteins (BMP) may explain part of such a phenomenon, since they act in combination to promote the various stages of bone formation. These proteins may potentially induce more than one cellular event and may have overlapping functions (19). The higher levels of BMP-7 found in the smoke-exposed animals could be a feedback response, in an attempt to compensate for the abrupt decrease in BMP-2, possibly to maintain new bone formation, since new bone formation has been reported to be limited rather than blocked (17). This could explain, on a molecular level, why there was no difference in bone formation at days 10 and 14 compared with the non-exposed animals.

Within the limits of the present study, it can be concluded that CSI may affect bone remodeling in the early periods after tooth extraction. Additional studies are needed to investigate more extensively the effects of smoking on bone healing.

\section{RESUMO}

O objetivo do estudo foi avaliar a influência da inalação da fumaça de cigarros (IFC) sobre os períodos iniciais de reparo ósseo alveolar. Quarenta ratos Wistar foram aleatoriamente divididos em teste: animais expostos à IFC, que se iniciou 3 dias antes das extrações mantendo-se até o sacrifício $(n=20)$ e controle (animais que não foram expostos à IFC; $\mathrm{n}=20$ ). Os animais tiveram seus segundos molares inferiores extraídos bilateralmente ( $\mathrm{n}=5 / \mathrm{grupo} /$ período) e foram sacrificados nos dias 3, 7, 10 e 14 dias após a cirurgia. Imagens digitalizadas foram analisadas de acordo com os seguintes parâmetros histométricos: tecido osteóide (OT), área remanescente (RA), tecido mineralizado (MT) e tecido não mineralizado (NMT) em cada alvéolo. Análise intergrupo mostrou que não houve diferença estatisticamente significante aos 3 dias ( $>0,05$ ) para todos os parâmetros. Aos 7 dias, a IFC influenciou negativamente $(p<0,05)$ o preenchimento ósseo mostrando diferença estatisticamente significante para os parâmetros tecido não mineralizado e defeito remanescente (MT: 36\%, NMT: 53\%, RA: $12 \%$; and MT: $39 \%$, NMT: $29 \%$, RA: $32 \%$, para controle e teste, respectivamente). No entanto, não houve diferença estatisticamente significante ( $>>0,05)$ aos 10 e 14 dias. Concluise que a IFC pode afetar o reparo ósseo alveolar inicial, o que pode ser crítico para a quantidade e qualidade da nova formação óssea em fumantes.

\section{REFERENCES}

1. Evian CI, Rosenberg ES, Coslet JG, Corn H. The osteogenic activity of bone removed from healing extraction sockets in humans. J Periodontol 1982;53:81-85.

2. Meechan JG, Macgregor ID, Rogers SN, Hobson RS, Bate JP, Dennison M. The effect of smoking on immediate post-extraction socket filling with blood and on the incidence of painful socket. Br J Oral Maxillofac Surg 1988;26:402-409.

3. Jones JK, Triplett RG. The relationship of cigarette smoking to impaired intraoral wound healing: a review of evidence and implications for patient care. J Oral Maxillofac Surg 1992;50:237240.

4. Yuhara S, Kasagi S, Inoue A, Otsuka E, Hirose S, Hagiwara H. Effects of nicotine on cultured cells suggest that it can influence the formation and resorption of bone. Eur J Pharmacol 1999;383: 387-393.

5. Tripton DA, Dabbous MK. Effects of nicotine on proliferation and extracellular matrix production of human gingival fibroblasts in vitro. J Periodontol 1995;66: 1056-1064.

6. Pinto JR, Bosco AF, Okamoto T, Guerra JB, Piza IG. Effects of nicotine on the healing of extraction sockets in rats. A histological study. Braz Dent J 2002;13:3-9.

7. Henemyre CL, Scales DK, Hokett SD, Cuenin MF, Peacock ME, Parker MH. Nicotine stimulates osteoclast resorption in a porcine marrow cell model. J Periodontol 2003;74:1440-1446.

8. Cattaneo V, Cetta G, Rota C, Vezzoni F, Rota MT, Gallanti A, Boratto R, Poggi P. Volatile components of cigarette smoke: Effect of acrolein and acetaldehyde on human gingival fibroblasts in vitro. J Periodontol 2000;71:425-432.

9. Ward KD, Klesges RC. A meta-analysis of the effects of cigarette smoking on bone mineral density. Calcif Tissue Int 2001;68:259270 . 
10. Saldanha JB, Casati MZ, Neto FH, Sallum EA, Nociti FH Jr. Smoking may affect the alveolar process dimensions and radiographic bone density in maxillary extraction sites: a prospective study in humans. J Oral Maxillofac Surg 2006;64:1359-1365.

11. Vanscheeuwijck PM, Teredesai A, Terpstra PM, Verbeeck J, Kuhl $\mathrm{P}$, Gerstenberg B. Evaluation of the potential effects of ingredients added to cigarettes. Part 4: subchronic inhalation toxicity. Food Chem Toxicol 2002;40:113-131.

12. César-Neto JB, Duarte PM, Sallum EA, Barbieri D, Moreno H Jr, Nociti FH Jr. A comparative study on the effect of nicotine administration and cigarette smoke inhalation on bone healing around titanium implants. J Periodontol 2003;74:1454-1459.

13. César-Neto JB, Benatti BB, Sallum EA, Casati, Nociti FH Jr. The influence of cigarette smoke inhalation and its cessation on the tooth-supporting alveolar bone: a histometric study in rats. J Periodontal Res 2006;41:118-123.

14. César-Neto JB, Benatti BB, Sallum EA, Sallum AW, Nociti FH Jr. Bone filling around titanium implants may benefit from smoking cessation: a histologic study in rats. J Periodontol 2005;76:14761481.
15. Benatti BB, César-Neto JB, Gonçalves PF, Sallum EA, Nociti FH Jr. Smoking affects the self-healing capacity of periodontal tissues. A histological study in the rat. Eur J Oral Sci 2005;113:400-403.

16. Daftari TK, Whitesides TE Jr, Heller JG, Goodrich AC, McCarey BE, Hutton WC. Nicotine on the revascularization of bone graft. An experimental study in rabbits. Spine 1994;19:904-911.

17. Giorgetti AP, Neto JB, Ruiz KG, Casati MZ, Sallum EA, Nociti Jr FH. Cigarette smoke inhalation modulates gene expression in sites of bone healing: a study in rats. Oral Surg Oral Med Oral Pathol Oral Radiol Endod 2010;110:447-452.

18. Lappin DF, Sherrabeh S, Jenkins WMM, Macpherson LMD. Effect of smoking on serum RANKL and OPG in sex, age and clinically matched supportive-therapy periodontitis patients. J Clin Periodontol 2007;34:271-277.

19. Bandyopadhyay A, Tsuji K, Cox K, Harfe BD, Rosen V, Tabin CJ. Genetic analysis of the roles of BMP2, BMP4 and BMP7 in limb patterning and skeletogenesis. PLoS Genet 2006;2:e216.

Received April 15, 2011 Accepted February 2, 2012 